\title{
Study of Medical-Assistance Equipment, Orthotics, Prosthetics, and Special Materials in the Unified Health System (SUS) in Brazil
}

\author{
Fotini Santos Toscas*; Thiago Rodrigues Santos; Eduardo Jorge Valadares Oliveira \\ Ministry of Health; Brasilia, DF, Brazil
}

\begin{abstract}
Medical Assistance Equipment (MAE), Orthotics, Prosthetics and Special Materials (OPSM) are strategic subsectors of the Industrial Health Complex (IHC).The dynamism and peculiar characteristics of these technologies characterize the innovation field and the short life cycle of technological developments. The study aims to consolidate the products in a single list by analyzing computerized databases and consulting the technical and other areas in the Ministry of Health. The study strengthens the data obtained and investigates the repeated items in the adopted criteria, crossing this information with previous publications. We established standards about MAE and OPSM in this study that have already been repeated in previous publications. Thus, there is a concentration of skills needs for these technologies in industrial and technological development, as well as in technological services requirement of these products.
\end{abstract}

Keywords: Equipment Approval. Diagnostic Equipment. Biomedical Technology Assessment. Unified Health System (SUS).

Medical Assistance Equipment (MAE) and Orthotics, Prosthetics and Special Materials (OPSM) are strategic subsectors of the Industrial Health Complex (CIS / IHC). The dynamism and particular characteristics of these technologies characterize the innovation environment, and their short technological life cycle, in addition to the relevance in health services and representativeness in technological and industrial development. According to the World Health Organization (WHO), the health products sector comprises more than 10 thousand categories of products and about 1.5 million different items. This broad range of products varies from low levels of technological intensity and high technological complexity.

The health care industry is one of the most dynamic sectors of the world economy, with an estimated annual turnover of $\$ 350$ billion in 2014 , with about 30,000 industries around the world, and more than 1 million employees. Brazil is the 7th largest market in the world, accounting for about $5 \%$ of the country's total health expenditure

Received on 10 February 2019; revised 10 March 2019.

Address for correspondence: Fotini Toscas. Deciis/SCTIE/ MS. Ministério da Saúde, Brasília, DF, Brazil. E-mail: fotini. toscas@saude.gov.br

J Bioeng. Biotech. Appl. Health 2019;2(1):21-26

C 2019 by SENAI CIMATEC. All rights reserved. and earning about the US \$ 11.7 billion in 2014 [1]. It is a future-bearing industry, as it is a source generating innovations incorporating technological advances in addition to the dynamic interrelations in the scope of IHC and the economy sector [2].

In the public sphere, the Ministry of Health promotes the MAE and OPSM's market for the acquisition of these technologies through transfers to public and private non-profit institutions, linked to the Unified Health System (SUS - Sistema Único de Saúde), as well as in the reimbursement of procedures that use these products for health.

Decentralization of public health management and resources is one of the guidelines of SUS. The procedure of the needs is upward, from the local to the federal level, following deliberative agencies and consistent with the requirements of the health programs and the budget available. As a result of the acquisition of health products predominantly occurs in a decentralized manner, where each agency is responsible for purchasing services, such as OPSM and MAE individually, using their bidding processes. Decentralized purchasing spreads available resources keeping track of the government purchasing power. On the other hand, the centralized acquisition process is difficult, because it requires the analysis of several technical and operational aspects, such as agreement among the subjects involved, 
planning, priorities, definitions of specifications and technical descriptions, technological design, cost analysis, acquisition, distribution/logistics, training, operation management, disposal and reverse logistics.

The Ministry of Health makes a constant effort to provide health units with the installation of new equipment. Most of this spending is on MAE, from the most straightforward needs of a Basic Health Unit (SUS) or Emergency Care Unit (ECU ( UPA) to the most sophisticated for health units and hospitals of medium and high complexity.

Currently,the health care of the population requires the use of some of these technologies, despite the fact that the emphasis is still on primary care, such as the Family Health Care Program (FHCP / PSF) or the Basic Health Units (BHU / UBA), in which MAE of low complexity are contemplated and indispensable for clinical procedures. Thus, the use of these technologies is a valuable tool to provide efficient care to the patient [3].

The main aim of this study presents an review study based on the databases of the computerized systems of the Ministry of Health (Information and Management System for Equipment and Materials (IMSEM /SIGEM) of National Health Fund (NHF ( FNS) and the Department of Informatics of SUS (DATASUS) for the year 2017, to identify the multiplication of MAE and OPSM in Brazil.

The searching was carried out in the following computerized systems of the Ministry of Health: SIGTAP - System of Management of the Table of Procedures, Medications, and OPM of SUS [4] and SIGEM - System of Management of Durable Equipment and Permanent Materials for SUS [5]. We search the data on the CONITEC portal - National Commission for the Incorporation of Technologies in SUS [6]. The research was also carried out in the ECRI database - Emergency Care Research Institute [7]. The study used a qualitative approach, starting from an analysis review in official documents of the Secretariat of Science, Technology and Strategic InputsSCTIE of the Ministry of Health-MS, related to the IHC and the strategic product lists. The available databases were used to search for market information and competitiveness of the health products industry.

The objective of the study is to consolidate the products in a single list by analyzing the computerized databases and consulting the technical areas of the Ministry of Health, in addition to cross-referencing information with previous publications of priority products. The first phase of the study was to search the National Report of Permanent Equipment and Materials (NRPEM/ RENEM) that can be financed by the Ministry of Health in 2016. We classified the items for diagnosis, therapy, and rehabilitation in this phase of research. We did not consider medical assistance, infrastructure, furniture, mobile units, vehicles, and computers in the study. The items delimited in the research were as following:

I Incidence: The aspects were selected based on in the approved quantitative, in which the proposals of investment projects were superior to 500 units in number and with a total value superior to $R \$ 1,000,000.00$. The study returned 16 items with these criteria. Total Value: The items were selected based on in the approved quantitative, in which the proposals of investment projects were higher than R \$1,000,000.00 regardless of the amount permitted. The study returned 58 items with these criteria.

II Unit Value: Items verified that the maximum allowed values for registration of investment projects were higher than $\mathrm{R} \$ 300,000.00$. Returned 36 items in this criterion.

The second phase of the study sought data on incorporation and Judicial Process:

I. Incorporation: MAE and OPSM chosen were selected and incorporated into the SUS procedures table by the National Commission for the Incorporation of Technologies into SUS (Conitec) and FNS, from 2013 to 2016. The study returned 32 items using these criteria.

II. Judicial Process: MAE and OPSM that 
needed a lawsuit in 2015 and 2016. The study included the items that are in legal proceedings underway in the Ministry of Health. The study returned 21 items in the judicial process.

In consultation with the final and technical areas of the Secretariat of Health Care - SAS and the Executive Secretariat of the Ministry of Health, the following data were collected:

I. Mapping of Care Requirements: In the first quarter of 2017, the Ministry of Health provided an Electronic Form (FormSUS) for the Health Services to indicate their needs in MAE, through the Health Care Secretariat (SAS). The study considered the data obtained in the mapping of health care demand and verified 22 items.

II. ABC Curve of OPSM: The Executive Secretariat of the Ministry of Health, through the Department of Health Economics, prepared an internal study containing the ABC curve of 100 procedures related to the use of OPSM. Our study considered a hundred items identified on the ABC curve.

Finally, the study considered international data, using the information from the list published in 2017 by the ECRI Institute of 10 medical technologies of most significant risk. This research reviewed the nomenclature and classification available in RENEM and SIGTAP of the Ministry of Health, due to that there is no standardization of item nomenclatures.

\section{Results and Discussion}

The study consolidated the data obtained to formulate a single list, and analyzed the items that were repeated in the criteria adopted. The final list was 192 consolidated items, with 20 issues appearing in three principles, described below in the study phases (emphasis on diagnostic imaging equipment, in vitro and in vivo diagnostic analyzers, cardioverter/defibrillator, anesthesia machine, video endoscopy and laparoscopy system, electric scalpel, diagnostic ultrasound, catheter, stents and prosthesis for cochlear implant). In four criteria appeared the multi-parameter monitor and the wheelchair, as well as pulmonary ventilator (Table 1).

The study considered all the criteria with the same relevance.

Table 1. Items using at least three criteria.

In vitro and in vivo diagnostic analyzer

Anesthesia Machine

X-ray Machine

Electric scalpel

Wheelchair

Cardioversion / Defibrillator

Catheters/Balloon catheter for peripheral angioplasty

Mammograph

Multiparameter Monitor

Prosthesis for cochlear implant

Flexible Video Endoscopy System

Video System Laparoscopy / Rigid Endoscopy

Coronary / pharmacological / non-covered stent

Computerized Tomography

Optical Coherence Tomography

Ultrasound

Pulmonary Ventilator

The study crossed the information with the previous publications with the theme of prioritization of equipment and materials for health. The publications observed:

i) list of priority equipment of Government Order No. 978/2008 of the Ministry of Health [8];

ii) Priority medical products defined after the crossing of SAS and ABIMO information from the study carried out by Eduardo Jorge Oliveira Valadares in 2010 [9];

iii) List of strategic products for the SUS of Ministry of Health Decree No. 3,089 / 2013 [10];

iv) List of strategic products for the SUS of the Ministry of Health Administrative Order No. 2.888 / 2014 [11]. Table 2 presents the list with the cross-referencing of the information found in the publications. 
Table 2. List of cross references.

\begin{tabular}{|c|c|c|c|c|}
\hline Item & $\begin{array}{c}\text { Government } \\
\text { Order } 978 / 2008 \\
\end{array}$ & $\begin{array}{c}\text { Oliveira, } \\
2010 \\
\end{array}$ & $\begin{array}{c}\text { Government } \\
\text { Order } 3,089 / 2013 \\
\end{array}$ & $\begin{array}{c}\text { Government } \\
\text { Order } 2,888 / 2014 \\
\end{array}$ \\
\hline $\begin{array}{l}\text { In vitro and in vivo } \\
\text { diagnostic analyzer }\end{array}$ & $\mathrm{x}$ & $\mathrm{x}$ & $\mathrm{x}$ & \\
\hline Anesthesia Machine & $\mathrm{x}$ & $\mathrm{x}$ & $\mathrm{x}$ & \\
\hline X-ray Machine & $\mathrm{x}$ & $\mathrm{x}$ & $\mathrm{x}$ & \\
\hline Electric scalpel & & & $\mathrm{x}$ & \\
\hline Wheelchair & & & $\mathrm{x}$ & \\
\hline Cardioversor / Defibrillator & $\mathrm{x}$ & $\mathrm{x}$ & $\mathrm{x}$ & $\mathrm{x}$ \\
\hline $\begin{array}{l}\text { Catheters / Balloon catheter } \\
\text { for peripheral angioplasty }\end{array}$ & $\mathrm{X}$ & $\mathrm{x}$ & $\mathrm{X}$ & \\
\hline Mammograph & $\mathrm{x}$ & $\mathrm{x}$ & & \\
\hline Multiparameter Monitor & $\mathrm{x}$ & & $\mathrm{x}$ & $\mathrm{x}$ \\
\hline Prosthesis for cochlear implant & & & $\mathrm{x}$ & $\mathrm{x}$ \\
\hline $\begin{array}{l}\text { Flexible Video Endoscopy } \\
\text { System }\end{array}$ & $\mathrm{x}$ & $\mathrm{x}$ & $\mathrm{x}$ & \\
\hline $\begin{array}{l}\text { Video System Laparoscopy / } \\
\text { Rigid Endoscopy }\end{array}$ & $\mathrm{x}$ & $\mathrm{x}$ & $\mathrm{x}$ & \\
\hline $\begin{array}{l}\text { Coronary / pharmacological / } \\
\text { non-covered stent }\end{array}$ & $x$ & $x$ & $\mathrm{X}$ & $\mathrm{x}$ \\
\hline Computerized Tomography & & $\mathrm{x}$ & & \\
\hline Optical Coherence Tomography & & & $\mathrm{x}$ & \\
\hline Ultrasound & $\mathrm{x}$ & $\mathrm{x}$ & $\mathrm{x}$ & \\
\hline Pulmonary Ventilator & $\mathrm{x}$ & $\mathrm{x}$ & $\mathrm{x}$ & \\
\hline
\end{tabular}

Maldonado and colleagues (2013) present examples of priority equipment necessary to build competencies:

i) dedicated chips for the hospital equipment industry, which can be used in numerous electromedical equipment;

ii) hemodialysis: filters used in hemodialysis;

iii) surgical articles and instruments made from engineering plastics - not by traditional methods of metallurgical industries;

iv) automated diagnostic equipment;

v) medical imaging: receptors, ultrasound devices, digital radiology; and

vi) material technology [2].

Landim and colleagues (2013) studied four segments of medical devices to detail aspects of the structure and the competitive dynamics of the sector. The selected sections were: in vitro diagnosis, diagnostic imaging, implants and electromedical. The study showed the following opportunities: directing efforts to internalize the assembly of smaller equipment, internalizing technologies for the manufacture of reagents for higher value-added tests, and stimulating the development and production of tests in the country. For imaging equipment, the study indicates that six devices were responsible for about $15 \%$ of the entire medical equipment sector deficit in 2012 (Magnetic Resonance Imaging, Ultrasound Imaging, Computed Tomography, Lightning Tubes X, Angiograph and Mammograph). In the implants segment, the study evaluated orthopedic and cardiovascular implants, with emphasis on the development of new materials, such as bioabsorbable and miniaturization of implants with embedded electronics. Finally, electromedical items, with focus on ventilators 
and vital signs monitors, the study indicates the use of remote monitoring through Information and Communication Technology, as well as the use of bright surgical rooms with integrated systems [12].

\section{Conclusion}

MAE and OPSM identified in this study have been corroborated in previous publications. Of the seventeen items identified as a priority in 2017 , twelve were included in the 2008 list of strategic products. This fact shows a concentration of skills needs for these technologies in industrial and technological development, as well as in the technologic services that these products require. The study also presents the peculiar characteristics of the market with a tendency to conglomerates and oligopolies. With recent and intense acquisitions, in particular, in the subsector of diagnosis by imaging and electromedical life support, small and medium-sized national companies focus on the innovation process and competitiveness level in the external market. These changes in the market have a significant impact on the supply and diffusion of these technologies. Several efforts have been made to mitigate technological vulnerability and also to minimize technological assistance gaps. The plan to expand radiotherapy is an example, through the state's purchasing power, not only increased bargaining power in the procurement process but also increased the national productive and technological system through technological compensation.

As a future perspective, technological relevance will be the tools to solve challenges and also strengthen the purchasing power of the State is highlighted. The new Framework for Science, Technology, and Innovation, with Law number 13,243/2016, establishes that "public administration organizations, according to public interested, can directly contract ICT, non-profit private organizations or companies, individually or in consortiums, focused on research activities and recognized technological qualification, aiming to carry out research, development and innovation activities that involve technological risk, in order to solve specific technical problem or obtain product, service or process innovation" [13]. Still pending regulatory aspects, the technological view presents itself as a strategic tool to increase the use of the purchasing power of the State. State purchasing power is crucial to ensure the maximization of available resources and the expansion of health benefits, together with the knowledge of decisions that are required by a universal health system.

\section{References}

1. Abimed. Associação Brasileira da Indústria de Alta Tecnologia de Produtos para Saúde. Business Review Brasil e Healthcare Global.[Internet]. 2015 [acesso 10 out 2017]. Disponível em: http://intranet.abimed.org. br/noticias.aspx.

2. Maldonado, J, Gadelha CAG, Vargas, M, Costa, LS, Quental, C. O subsistema de base mecânica, eletrônica e de materiais do complexo econômico industrial da saúde: perspectivas para 2022/2030. Rio de Janeiro: Fiocruz/Ipea/Ministério da Saúde/Secretaria de Assuntos Estratégicos da Presidência da República, 2013. Vol.5.pp.81-117.ISBN 978-85-8110-019-7.

3. Brasil. Ministério da Saúde. Secretaria Executiva. Departamento de Economia da Saúde, Investimento e Desenvolvimento. Secretaria de Ciência, Tecnologia e Insumos Estratégicos. Departamento de Ciência e Tecnologia. Mapeamento e diagnóstico da gestão de equipamentos médico-assistenciais nas regiões de atenção à saúde do projeto QualiSUS-Rede/Ministério da Saúde, Secretaria de Ciência, Tecnologia e Insumos Estratégicos, Departamento de Ciência e Tecnologia. - Brasília: Ministério da Saúde, 2016.

4. Brasil. Sistema de Gerenciamento de Equipamentos e Materiais Permanentes Financiáveis para o SUS. [Internet]. 2017 [acesso 10 out 2017]. Disponível em: http://www.fns.saude.gov.br/visao/ pesquisarEquipamentos.jsf.

5. Brasil. Sistema de Gerenciamento da Tabela de Procedimentos, Medicamentos e OPM do SUS. [Internet]. 2017 [acesso 10 out 2017]. Disponível em: http://sigtap.datasus.gov.br/tabela-unificada/app/sec/ inicio.jsp.

6. Brasil. Comissão Nacional de Incorporação de Tecnologias no SUS. [Internet]. 2017 [acesso 10 out 2017]. Disponível em: http://conitec.gov.br/.

7. ECRI. Emergency Care Research Institute. [Internet]. 2017 [acesso 10 out 2017]. Disponível em: https://www. ecri.org/Pages/default.aspx. 
8. Brasil. Portaria $\mathrm{n}^{\circ} 978$, de 16 de maio de 2008 , que dispõe sobre a lista de produtos estratégicos, no âmbito do Sistema Único de Saúde, com a finalidade de colaborar com o desenvolvimento do Complexo Industrial da Saúde e institui a Comissão para Revisão e Atualização da referida lista.

9. Oliveira, E.J.V. "Engenharia clínica aplicada à definição e Implementação de uma proposta desenvolvimentista para o sistema nacional de inovação de produtos médicos". Campinas, SP:[s.n],2010.

10. Brasil. Portaria $n^{\circ} 3.089$, de 11 de dezembro de 2013, anexo com a lista de produtos estratégicos para o Sistema Único de Saúde (SUS).

11. Brasil. Portaria $n^{\circ} 2.888$, de 30 de dezembro de 2014, que define a lista de produtos estratégicos para o Sistema Único de Saúde (SUS), nos termos do anexo a esta Portaria.
12. Ladin.A., Gomes.R., Pimentel.V., Reis. C., Pieroni.J.P. Equipamentos e tecnologias para saúde: oportunidades para uma inserção competitiva da indústria brasileira.

Banco Nacional de Desenvolvimento Econômico e Social. Brasil, 2013.

13. Brasil. Lei $\mathrm{n}^{\mathrm{o}} 13.243$, de 11 de janeiro de 2016, que dispõe sobre estímulos ao desenvolvimento científico, à pesquisa, à capacitação científica e tecnológica e à inovação e altera a Lei no 10.973, de 2 de dezembro de 2004, a Lei no 6.815, de 19 de agosto de 1980, a Lei no 8.666, de 21 de junho de 1993, a Lei no 12.462, de 4 de agosto de 2011, a Lei no 8.745, de 9 de dezembro de 1993, a Lei no 8.958, de 20 de dezembro de 1994, a Lei no 8.010, de 29 de março de 1990, a Lei no 8.032, de 12 de abril de 1990, e a Lei no 12.772, de 28 de dezembro de 2012, nos termos da Emenda Constitucional no 85, de 26 de fevereiro de 2015 . 